\title{
Explaining Hungarian Defence Spending Trends, 2004-2019
}

\begin{abstract}
Defence has become a central issue of strategic discourse among NATO's Central European member states after 2014, following the Russian aggression against Ukraine. Reinforcing capabilities and readiness within the framework of collective defence requires much from these countries in terms of strategic thinking, capability planning, defence procurement and modernisation - and as a central element to realising their aims, in terms of funds for defence. U.S. President Donald Trump's sustained criticism calling for 'more fair' burden sharing among member states, resulting in the adoption of the Wales Declaration on the Transatlantic Bond 1 (Defence Pledge), further incentivised member states' willingness to dynamise their efforts. Since then, many European countries - some significantly - have increased their defence budgets and other forms of contribution. This paper offers an overview and analysis of Hungarian defence spending trends since the country's accession to the European Union in 2004,2 as this can highlight what has been achieved in this specific 'enabling' field in the past couple of years to counterbalance the trend of underfinancing prevalent for a decade. The author argues that the increased attention and resources dedicated to defence and the significant modernisation drive are part of an overarching normalisation process taking place in Hungary. Four indicative scenarios are developed in the paper based on the GDP growth trends and planned continuous increase of the defence budget, showing that independent of the (forecasted) GDP growth rate, the $2 \%$ target in terms of GDP would only be met in case of a more intensive, $0.2 \%$ annual increase scenario.
\end{abstract}

Keywords: Hungary, NATO, European Union, defence spending, strategy, Zrínyi 2026

\section{Introduction}

The current paper is the first part of a series that will synthesise and assess the strategic processes of the Hungarian defence policy. Subsequent papers will map up the evolving strategic landscape in terms of threat perception, strategic alternatives and the current initiatives of the Hungarian defence policy, as well as the overarching defence modernisation program, 'Zrínyi 2026. The aim of these papers is to gain a better understanding of the

\footnotetext{
The Wales Declaration on the Transatlantic Bond, [online], 05.09.2014. Source: Nato.int [10.02.2019.]

This milestone offers a practical starting point for the analysis, as Hungarian security policy experts themselves argue that after accomplishing the accession to the Euro-Atlantic defence (NATO-1999) and European political-economic integrations (EU-2004), the political and military elite of the country felt 'satisfied' with the safe and stable conditions and diverted their attention - and resources - to other policy fields. This resulted in a restrained willingness to spend on defence. See for example TÁLAs Péter: Negyedszázad magyar haderőreform-kísérleteinek vizsgálódási kereteiről. In: Tálas Péter - Csıki Tamás (eds.): Magyar biztonságpolitika, 1989-2014 - Tanulmányok. NKE NI SVKK, Budapest, 2014, pp. 18-19.
} 
drivers of the Hungarian defence policy, including those opportunities and challenges that the Hungarian Defence Forces (HDF) may face during the next years.

One of the central arguments of these papers is that the increased attention and resources dedicated to defence and the significant modernisation drive are part of an ongoing overarching normalisation process. This normalisation process in many respects aims to change outdated strategies and doctrines, replace worn-out equipment, re-develop branches that had been given up and reverse those trends, including political neglect, societal resignation, residual financing and technological abandonment that had been weakening the HDF. At the same time, the Hungarian Defence Forces must meet the challenges of a rapidly changing security environment, sometimes in unanticipated ways, therefore, as a secondary drive, such qualitative development must take place in terms of manpower, equipment, institutions and doctrines that would serve well both for providing national and collective defence, as well as executing crisis management tasks.

\section{Getting our primary resources}

As both the Ministry of Defence and the Hungarian Defence Forces exercise a very restrictive stance on releasing hard data related to the funding, manning or strength of the HDF going beyond the necessary minimum requirements to ensure budgetary transparency, it is a rather challenging task to acquire reliable open-source data on issues such as defence spending. According to the Homeland Defence Act (Par. 38, Sec. 7.), last modified in 2018, "data related to the institutional structure, functioning, military equipment, munitions and materiel of the Hungarian Defence Forces are non-public for 30 years due to their sensible nature in terms of homeland defence and national security. The release of such data is to be authorized by the Minister of Defence upon the recommendation of the Commander of the Hungarian Defence Forces upon deliberation of homeland defence and national security interests" ${ }^{3}$ This provision has become even stricter over the years, since in its original version in 2011, the Chief of Defence was still authorised to release such data (for meeting inquiries on behalf of the media or the public in a timely manner).

Still, all data and information included in this paper are publicly available, based on the budgetary laws that the Hungarian Parliament must adopt and make publicly available. Annual budgets for the next fiscal year (FY) ${ }^{4}$ are usually approved by early summer (June, July) each year, before MPs leave for their summer administrative break, while Final Accounting Acts that provide controlling for the respective FYs' budgets are approved towards the end of the subsequent year (November, December). Thus, for example the Annual Budget for FY 2017 was adopted on 24 June 2016, ${ }^{5}$ while the Final Accounting Act for the FY 2017 budget was approved on 27 November $2018 .{ }^{6}$ This analysis builds its con-

\footnotetext{
2011. évi CXIII. törvény a honvédelemről és a Magyar Honvédségről, valamint a különleges jogrendben bevezethető intézkedésekről, [online], 27.07.2011. Source: Net.jogtar.hu [10.02.2019.]

Fiscal years coincide with calendar years in Hungary.

2016. évi XC. törvény Magyarország 2017. évi központi költségvetéséről, [online], 24.06.2016. Source: Net.jogtar.hu [10.02.2019.]

6 2018. évi LXXXIV. törvény a Magyarország 2017. évi központi költségvetéséről szóló 2016. évi XC. törvény végrehajtásáról, [online], 27.11.2018. Source: Magyarkozlony.hu [10.02.2019.]
} 
clusions on the data derived from these legal sources and the open-source data provided by NATO regarding Hungary (and all other member states).

Given the unquestioned role and importance of visibility, transparency and accountability towards democratic institutions and the people - at the same time acknowledging and respecting the sensitive nature of many information and hard data that relate to the defence forces and accepting a somewhat restrictive stance and careful deliberation based upon national security interests -, a more transparent information policy on the above mentioned issues might be considered, since it was the case prior to 2011, and because such practice is followed by many allied nations. The benefits of such practice - beyond sustaining scholarly and analytical endeavours - would be manifold. For example, these would manifest in intensifying public discourse about defence (not only the costs but also the benefits of defence), thus legitimising pubic spending in this field, also justifying the development programs that are being undertaken. Besides, fact-based information sharing could increase public awareness and knowledge about defence and strengthen societal support for the HDF. Moreover, allies would also gain a clearer picture of what the Hungarian Government and the HDF are planning, thus creating a room for a better understanding of the potential fields of cooperation bilaterally and regionally as well.

\section{Defence spending trends, 2004-2019}

Once enjoying the benefits of NATO (1999) and EU membership (2004) and a less volatile period of international security from a (Central) European perspective, subsequent Hungarian governments began to pay less attention to defence and adopted a restrained approach towards funds. As a first step, in 2004, compared to the provisionally approved budget of 347 billion Hungarian Forints (HUF), ${ }^{7}$ more than $10 \%$ less, close to 312 billion HUF was provided for the MoD. ${ }^{8}$ With the increased burden of international engagement on the Balkans and in Afghanistan, defence expenditures were moving in the following years in a $+/-10 \%$ threshold on average, and six years later, in 2010, were still standing around the same level (317.8 billion HUF) as in 2005 (Figure 1).

The effects of the financial and economic crisis that emerged in 2008 had been realised with a shocking $16 \%$ drop of funds in 2010 , and the slightly decreasing trend in nominal terms lasted until 2014. Ten years after the Hungarian EU accession, nominal defence funds were $17.6 \%$ lower than in 2004 - not mentioning the real value loss attributed to (defence) inflation. Not surprisingly, this decade gave way to hardly any modernisation within the HDF, with significant capability losses, particularly after 2009.

All data represent (then) current values throughout the analysis.

2005. CXVIII. törvény a Magyar Köztársaság 2004. évi költségvetéséről és az államháztartás hároméves kereteiről szóló 2003. évi CXVI. törvény végrehajtásáról, [online], 11.11.2005. Source: Net.jogtar.hu [10.02.2019.] 
Starting in 2012, normalisation and then the gradual shift to an increasing path took place in three steps:

- Government Decree No. 1046/2012 ${ }^{9}$ was adopted to stop the decline at least by keeping the nominal value of the defence budget of 2012 for the years 2013-2015, and then increasing the budget by $0.1 \%$ of the GDP annually until 2012, thus reaching $1.39 \%$ of the GDP in sum by 2022. Still, FY 2013-2014 saw further nominal decrease - though with a slowing tendency, hitting the bottom in 2014 with 256.75 billion HUF. By that time, the nominal defence budget was almost 54.5 billion HUF (17.5\%) lower than in 2004.

- Nominal increase began in 2015 with a $14.74 \%$ leap. To further reinforce this process, Government Decree No. $1273 / 2016^{10}$ provided for a sustained annual $0.1 \%$ increase in terms of GDP for the years 2017-2026, aiming to reach 1.79\% of GDP by the end of the decade-long development period.

- To meet sustained political expectations and the outlined resource-demand of national capability development within the 'Zrínyi 2026' - National Defence and Armed Forces Development Program, Government Decree No. 1283/2017 $7^{11}$ went further: accordingly, with higher-ratio annual increases, the Hungarian defence budget was set to reach $2 \%$ of the GDP by 2024, and from 2025 onwards the achieved level should be sustained.

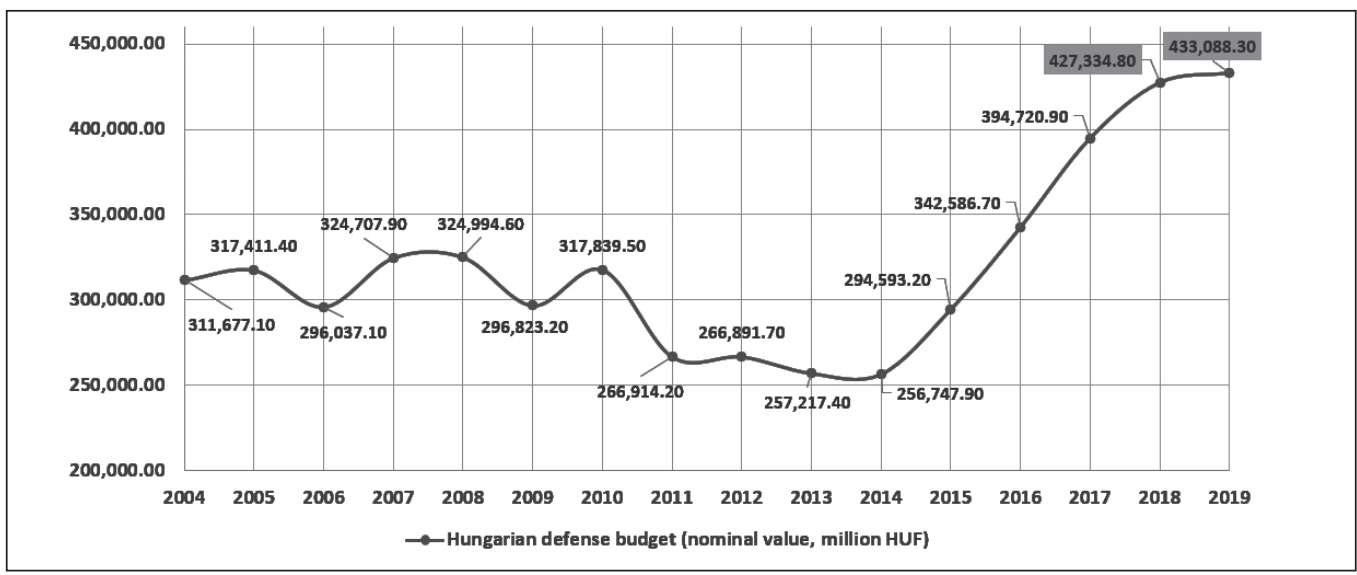

Figure 1: The nominal value of the Hungarian defence budget, 2004-2019

Source: The respective annual state budgets' Final Accounting Acts for FY 2004-2017; for FY 2018-2019 (highlighted) data from the approved State Budget are indicated as no Final Accounting Act has been adopted yet.

9 1046/2012. Kormányhatározat a honvédelmi kiadások és a hosszú távú tervezés feltételeinek megteremtését szolgáló költségvetési források biztosításáról, [online], 29.02.2012, p. 5340. Source: Kozlonyok.hu [10.02.2019.]

10 1273/2016. Kormányhatározat a honvédelmi kiadások és a hosszú távú tervezés feltételeinek megteremtését szolgáló költségvetési források biztosításáról, [online], 07.06.2016. Source: Net.jogtar.hu [10.02.2019.]

11 1283/2017. Kormányhatározat a honvédelmi kiadások és a hosszú távú tervezés feltételeinek megteremtését szolgáló költségvetési források biztosításáról szóló 1273/2016. Kormányhatározat módosításáról, [online], 02.06.2017. Source: Net.jogtar.hu [10.02.2019.] 
2016 (16.29\%) and 2017 (15.22\%) saw further significant annual increase respectively, and the adopted budgets for 2018 and 2019 also continue this trend of year-on-year growth, though at a decreasing rate. In nominal terms, the Hungarian defence budget increased by $70 \%$ since its lowest level in 2014.

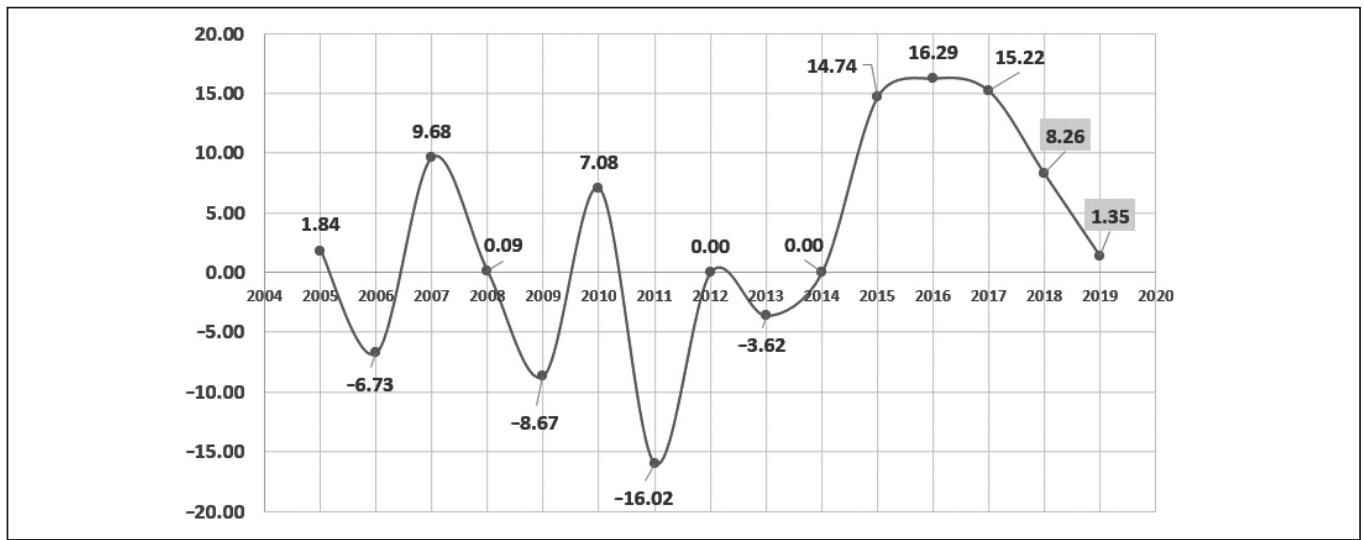

Figure 2: The annual change of the Hungarian defence expenditure compared to the previous year respectively

Source: The respective annual state budgets' Final Accounting Acts. For the years 2018-2019 (highlighted) data for the provisionally approved budget are indicated as no Final Accounting Act has been adopted yet.

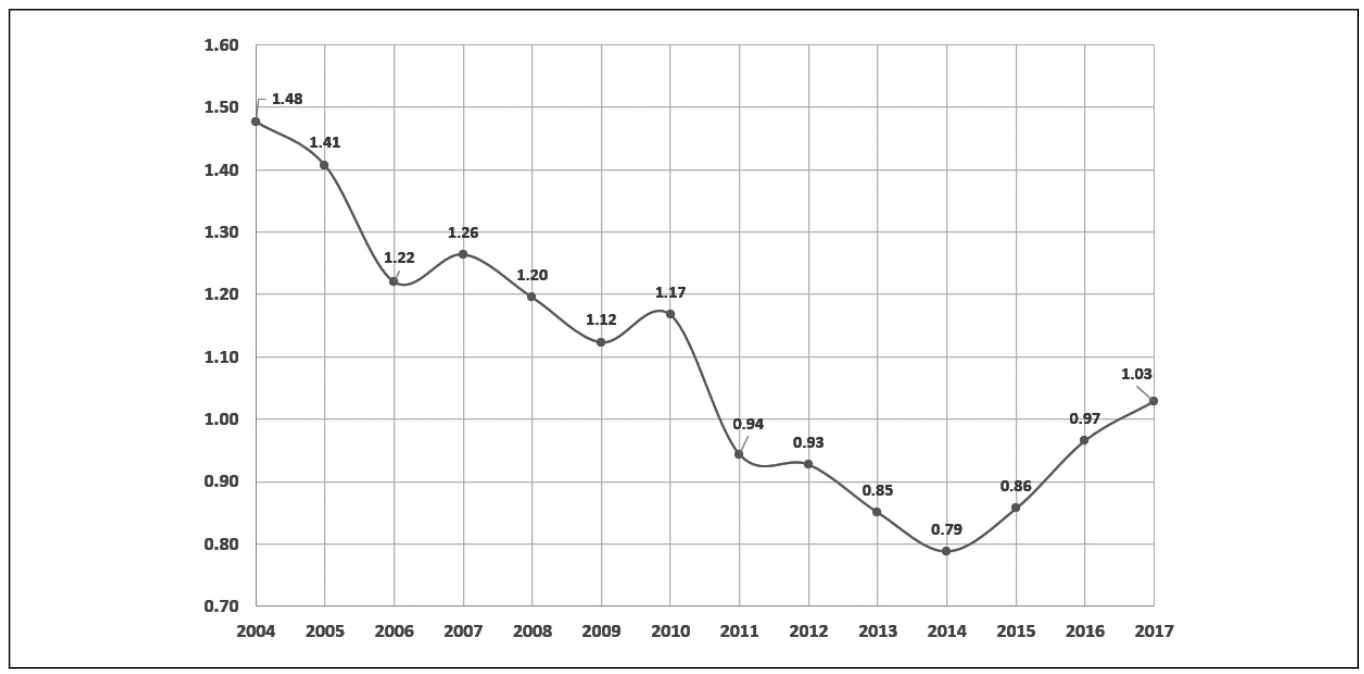

Figure 3: The Hungarian defence budget in terms of GDP, 2004-2017

Source: Calculated by the author based on defence expenditures data (the respective annual state budgets'

Final Accounting Acts) and the GDP data published by the Hungarian Central Statistical Office. ${ }^{12}$

12 A bruttó hazai termék (GDP) értéke és volumenindexei (2000-), [online], 10.10.2018. Source: Ksh.hu [10.02.2019.] GDP data for 2017 are the estimates of the Hungarian Central Statistical Office. 
Defence spending in terms of the GDP (Figure 3) had also been decreasing in the period 2004-2014 with brief pauses in 2007 and 2010, then hitting rock bottom in 2014 with only $0.79 \%$. Since then, a gradual increase has begun - which runs parallel with the general GDP growth (Figure 4), thus yielding in the sizeable nominal expansion of the Hungarian defence budget shown in Figure 1.

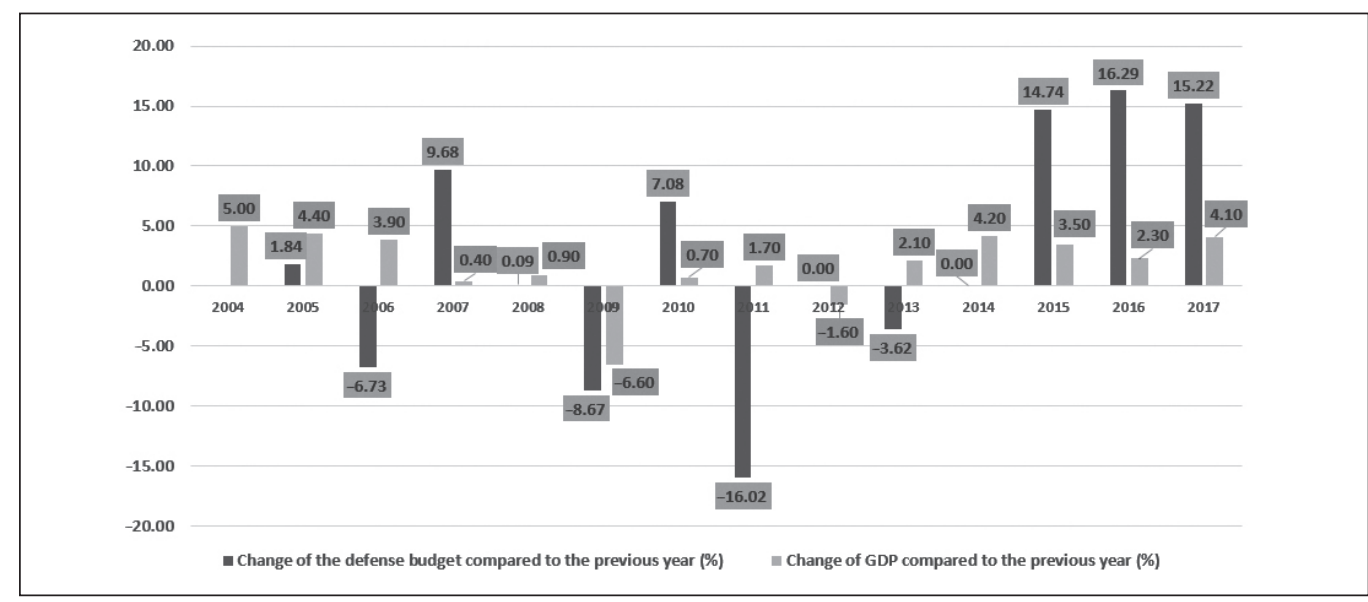

Figure 4: The parallel annual variance of GDP and defence expenditure in Hungary, 2004-2017

Source: Data are derived from previous calculations in this study.

\section{Defence spending forecast: indicative scenarios}

Regarding the prospects of meeting the $2 \%$ target by 2024 , we can formulate approximate estimates based on various scenarios. Four indicative scenarios are outlined below, based on two variables: 1 . the prognosis of GDP growth following the average annual growth of a) the examined 14 years (for FY 2004-2017, 1.8\% annually) and b) for the past 5 years (for FY 2013-2017, 3.24\% annually); ${ }^{13} 2$. the annual growth scenarios of the defence budget in terms of GDP, by i) $0.1 \%$ or ii) $0.2 \% .{ }^{14}$

13 Calculations in these indicative scenarios (carried out by the author) are based on the GDP dataset of the Hungarian Central Statistical Office. The statistical average of GDP growth had been calculated for FY 2004-2017 and FY 20132017 respectively, for the timespan of which we have available data. GDP data for 2017 are the estimates of the Hungarian Central Statistical Office. Data forecasts within the scenarios take FY 2017 as the base year for GDP as this is the last year for which we have official data, while FY 2019 is taken as the base year of the defence budget forecast, as currently the last official data is available for this year.

The two timespans had been chosen to indicate the full examined period (2004-2017) that included a deep recession period as well, and a positive scenario, the post-crisis growth period (2013-2017).

14 The two scenarios regarding the volume of defence budget growth had been chosen as $0.1 \%$ as the base scenario (the commitment undertaken by the government already in 2012) and $0.2 \%$ as a scenario showing higher commitment (and the necessity to provide extra funds). 
Table 1: The low GDP growth and low defence budget increase scenario

\begin{tabular}{|l|r|r|r|}
\cline { 2 - 4 } \multicolumn{1}{c|}{ Scenario I } & \multicolumn{1}{c|}{$\mathbf{2 0 2 4}$} & \multicolumn{1}{c|}{$\mathbf{2 0 2 5}$} & \multicolumn{1}{c|}{$\mathbf{2 0 2 6}$} \\
\hline $\begin{array}{l}\text { Total GDP (million HUF) by +1.8\% average annual growth } \\
\text { until 2026 }\end{array}$ & $43,456,799.19$ & $44,239,021.58$ & $45,035,323.97$ \\
\hline 2\% of GDP spent on defence would be (million HUF) & $869,135.98$ & $884,780.43$ & $900,706.48$ \\
\hline $\begin{array}{l}\text { Nominal value of the defence budget (million HUF) by } \\
+0.1 \% \text { annual growth in terms of GDP }\end{array}$ & $642,823.05$ & $687,062.07$ & $732,097.39$ \\
\hline Meets the 2\% target? & $1.48 \%$ & $1.55 \%$ & $1.63 \%$ \\
\hline
\end{tabular}

Source: Calculations done by the author based on official GDP data.

Table 2: The high GDP growth and low defence budget increase scenario

\begin{tabular}{|l|r|r|r|}
\cline { 2 - 4 } \multicolumn{1}{c|}{ Scenario II } & \multicolumn{1}{c|}{$\mathbf{2 0 2 4}$} & \multicolumn{1}{c|}{$\mathbf{2 0 2 5}$} & \multicolumn{1}{c|}{$\mathbf{2 0 2 6}$} \\
\hline $\begin{array}{l}\text { Total GDP (million HUF) by +3.24\% average annual } \\
\text { growth until 2026 }\end{array}$ & $47,946,809.48$ & $49,500,286.11$ & $51,104,095.38$ \\
\hline 2\% of GDP spent on defence would be (million HUF) & $958,936.19$ & $990,005.72$ & $1,022,081.91$ \\
\hline $\begin{array}{l}\text { Nominal value of the defence budget (million HUF) by } \\
+0.1 \% \text { annual growth in terms of GDP }\end{array}$ & $658,239.99$ & $707,740.28$ & $758,844.38$ \\
\hline Meets the 2\% target? & $1.37 \%$ & $1.43 \%$ & $1.49 \%$ \\
\hline
\end{tabular}

Source: Calculations done by the author based on official GDP data.

Table 3: The high GDP growth and high defence budget increase scenario

\begin{tabular}{|l|r|r|r|}
\cline { 2 - 4 } \multicolumn{1}{c|}{ Scenario III } & \multicolumn{1}{c|}{$\mathbf{2 0 2 4}$} & \multicolumn{1}{c|}{$\mathbf{2 0 2 5}$} & \multicolumn{1}{c|}{$\mathbf{2 0 2 6}$} \\
\hline $\begin{array}{l}\text { Total GDP (million HUF) by +3.24\% average annual } \\
\text { growth until 2026 }\end{array}$ & $47,946,809.48$ & $49,500,286.11$ & $51,104,095.38$ \\
\hline 2\% of GDP spent on defence would be (million HUF) & $958,936.1896$ & $990,005.72$ & $1,022,081.91$ \\
\hline $\begin{array}{l}\text { Nominal value of the defence budget (million HUF) by } \\
+0.2 \% \text { annual growth in terms of GDP }\end{array}$ & $883,391.68$ & $982,392.26$ & $1,084,600.46$ \\
\hline Meets the 2\% target? & $1.84 \%$ & $1.98 \%$ & $2.12 \%$ \\
\hline
\end{tabular}

Source: Calculations done by the author based on official GDP data.

Table 4: The low GDP growth and high defence budget increase scenario

\section{Scenario IV}

Total GDP (million HUF) by $+1.8 \%$ average annual growth until 2026

$2 \%$ of GDP spent on defence would be (million HUF)

Nominal value of the defence budget (million HUF) by $+0.2 \%$ annual growth in terms of GDP

Meets the $2 \%$ target?

\begin{tabular}{|r|r|r|}
\hline \multicolumn{1}{|c|}{$\mathbf{1 0 2 4}$} & \multicolumn{1}{c|}{$\mathbf{2 0 2 5}$} & \multicolumn{1}{c|}{$\mathbf{2 0 2 6}$} \\
\hline $43,456,799.19$ & $44,239,021.58$ & $45,035,323.97$ \\
\hline $869,135.98$ & $884,780.43$ & $900,706.48$ \\
\hline $852,557.80$ & $941,035.84$ & $1,031,106.48$ \\
\hline $1.96 \%$ & $2.13 \%$ & $2.30 \%$ \\
\hline
\end{tabular}

Source: Calculations done by the author based on official GDP data. 
As we can see, the summarised assessment in Table 5, independent of the GDP growth rate, the $2 \%$ target in terms of GDP would not be met by 2024, neither by 2026, if the annual growth of the defence budget would be set for $0.1 \%$ only. While in case of a more intensive, $0.2 \%$ annual increase scenario the target could be met by 2025 in the low growth scenario and by 2026 in case of the high growth scenario regarding GDP.

Table 5: Four indicative scenarios combining low and high GDP growth cases with normal and increased defence budget growth rates, and their derived results with regards to reaching the $2 \%$ NATO spending target by 2024

\begin{tabular}{|l|l|l|}
\cline { 2 - 3 } \multicolumn{1}{c|}{} & $\begin{array}{l}\text { a) 1.8\% GDP growth prognosis } \\
\text { (average of FY 2004-2017) }\end{array}$ & $\begin{array}{l}\text { b) 3.24\% GDP growth prognosis } \\
\text { (average of FY 2013-2017) }\end{array}$ \\
\hline $\begin{array}{l}\text { i) } 0.1 \% \text { annual growth of the } \\
\text { defence budget in terms of GDP }\end{array}$ & $\begin{array}{l}\text { Scenario I falls short of the 2\% } \\
\text { defence spending target by 2024 } \\
\text { and 2026 as well }\end{array}$ & $\begin{array}{l}\text { Scenario II falls short of the 2\% } \\
\text { defence spending target by 2024 } \\
\text { and 2026 as well }\end{array}$ \\
\hline $\begin{array}{l}\text { ii) } 0.2 \% \text { annual growth of the } \\
\text { defence budget in terms of GDP }\end{array}$ & $\begin{array}{l}\text { Scenario III falls short of the 2\% } \\
\text { defence spending target by 2024 } \\
\text { but reaches it in 2025 }\end{array}$ & $\begin{array}{l}\text { Scenario IV falls short of the 2\% } \\
\text { defence spending target by 2024 } \\
\text { but reaches it in 2026 }\end{array}$ \\
\hline
\end{tabular}

Source: Calculations done by the author based on official GDP data.

Even though these scenarios are built on a trend-based data forecast that is likely not to continue in a linear way (accelerated by better economic performance or decelerated by another period of recession, as well as changed by targeted political decisions regarding higher defence investments), it is useful to keep in mind that the original commitment to sustain an annual $0.1 \%$ increase might not be enough to meet the $2 \%$ target in terms of GDP. Considering the trend, however, the nominal increase would be substantial in any case: in Scenario I the change would be $+69 \%$ (732,097.39 million HUF) compared to 2019 (433,088.30 million HUF), in Scenario II +75.2\% (758,844.38 million HUF), in Scenario III $+138.1 \%(1,031,106.48$ million HUF) and in Scenario IV $+150.43 \%(1,084,600.46$ million HUF).

Furthermore, it is worth to note - as we can see in Figure 5 - that in the period 2004-2017 the realised defence budget has on average been $9.2 \%$ higher throughout the years than the final budget proposal acted in law. (This final proposal has also tended to be higher than the original proposal formulated at the beginning of the annual budget debate initiated by the government and the Parliament.) 


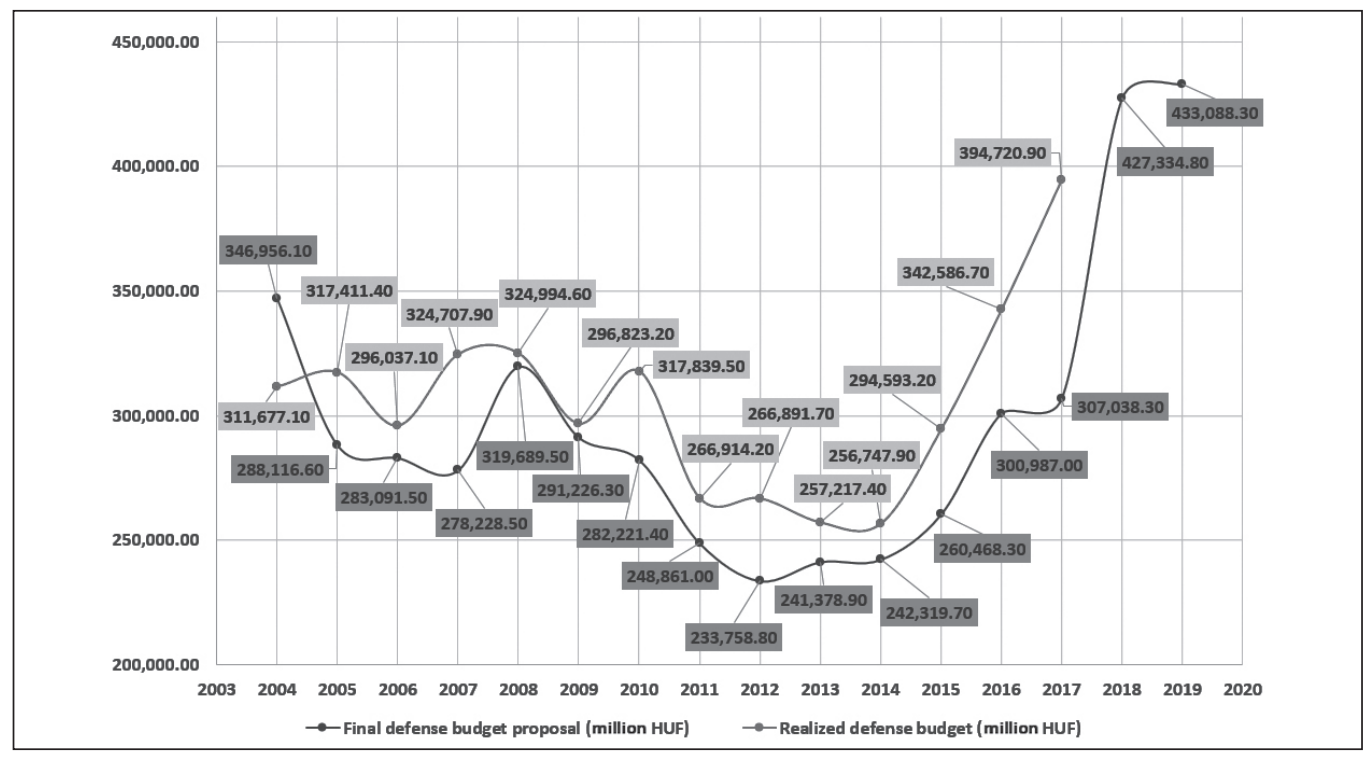

Figure 5: The nominal proposed (dark grey) and realised (light grey) Hungarian defence budget values, 2004-2019

Source: The respective annual state budgets' Final Accounting Acts. For the years 2018-2019, the provisionally approved budget is indicated only, as no Final Accounting Act has been adopted yet, therefore there are no available values for the realised budget.

Thus, we could expect that for FY 2018-2019 the actual funds available for defence would be higher than indicated in the figure. Indeed, for 2018, an extra 72,048.7 million HUF was granted for the Ministry of Defence. ${ }^{15}$ Also, for 2019, 79,759.9 million HUF as extra funds had been provided since the central budget was approved, thus - as currently seen - altogether 512,846.2 million HUF (1.17\% of the estimated GDP $)^{16}$ are available for the MoD. ${ }^{17}$ Having this in mind, it is also possible that - within the limits of the indicative scenarios described above - three out of the four scenarios will result in reaching the $2 \%$ spending target in terms of GDP by 2024.

\section{Conclusions}

The increased attention and resources dedicated to defence and the significant modernisation drive are part of an overarching normalisation process taking place in Hungary, that in many respects aims to change outdated strategies and doctrines, replace worn-out equipment, re-develop branches that had been given up and reverse those trends, including

15 Detailed explanation of the defence budget request 2018. XIII. Honvédelmi Minisztérium, [online], 08.06.2017. Source: Parlament.hu [10.02.2019.]

16 Detailed explanation of the defence budget request 2019. XIII. Honvédelmi Minisztérium, [online], 20.06.2018. Source: Parlament.hu [10.02.2019.]

17 These developments have not been noted in Figure 2 as might be subject to change. The final official balance of these years in terms of the provided and used funds will be available in the Final Accounting Acts by the end of 2019 and 2020 respectively. 
political neglect, societal resignation, residual financing and technological abandonment, that had been weakening the Hungarian Defence Forces.

The studied trends reveal that in 2014, ten years after Hungary joined the European Union, nominal defence funds were $17.6 \%$ lower than in 2004 - not mentioning the real value loss attributed to (defence) inflation. Nominal increase began in 2015 with a $14.74 \%$ leap and the increasing trend has been preserved since. To meet sustained political expectations and the outlined resource-demand of national capability development within the 'Zrínyi 2026' - National Defence and Armed Forces Development Program, the Hungarian defence budget is set to reach 2\% of the GDP by 2024, and from 2025 onwards the achieved level should be sustained. In nominal terms, by 2019 the Hungarian defence budget increased by $70 \%$ since its lowest level in 2014 . The approved nominal budget of the HDF for 2019 was 433.1 billion HUF (1.35 billion EUR), supplemented by an additional 79.7 billion HUF ( 0.25 billion EUR) since then - altogether making up 512.8 billion HUF (1.6025 billion EUR), or $1.17 \%$ of the forecasted GDP.

The four indicative scenarios developed in the paper, based on the GDP growth trends and planned continuous increase of the defence budget, show that independent of the (forecasted) GDP growth rate, the $2 \%$ target in terms of GDP would only be met in case of a more intensive, $0.2 \%$ annual increase scenario: by 2025 in the low growth scenario and by 2026 in a high GDP growth scenario.

\section{REFERENCES}

A bruttó hazai termék (GDP) értéke és volumenindexei (2000-), [online], 10.10.2018. Source: Ksh.hu [10.02.2019.] GDP data for 2017 are the estimates of the Hungarian Central Statistical Office.

Detailed explanation of the defence budget request 2018. XIII. Honvédelmi Minisztérium, [online], 08.06.2017. Source: Parlament.hu [10.02.2019.]

Detailed explanation of the defence budget request 2019. XIII. Honvédelmi Minisztérium, [online], 20.06.2018. Source: Parlament.hu [10.02.2019.]

The Wales Declaration on the Transatlantic Bond, [online], 05.09.2014. Source: Nato.int [10.02.2019.]

TÁLAs Péter: Negyedszázad magyar haderőreform-kísérleteinek vizsgálódási kereteiről. In: TÁLAs Péter - Csiki

Tamás (eds.): Magyar biztonságpolitika, 1989-2014 - Tanulmányok. NKE NI SVKK, Budapest, 2014, pp. 9-22.

2005. CXVIII. törvény a Magyar Köztársaság 2004. évi költségvetéséről és az államháztartás hároméves kereteiről szóló 2003. évi CXVI. törvény végrehajtásáról, [online], 11.11.2005. Source: Net.jogtar.hu [10.02.2019.]

2011. évi CXIII. törvény a honvédelemről és a Magyar Honvédségről, valamint a különleges jogrendben bevezethető intézkedésekről, [online], 27.07.2011. Source: Net.jogtar.hu [10.02.2019.]

2016. évi XC. törvény Magyarország 2017. évi központi költségvetéséről, [online], 24.06.2016. Source: Net. jogtar.hu [10.02.2019.]

2018. évi LXXXIV. törvény a Magyarország 2017. évi központi költségvetéséről szóló 2016. évi XC. törvény végrehajtásáról, [online], 27.11.2018. Source: Magyarkozlony.hu [10.02.2019.]

1046/2012. Kormányhatározat a honvédelmi kiadások és a hosszú távú tervezés feltételeinek megteremtését szolgáló költségvetési források biztosításáról, [online], 29.02.2012, p. 5340. Source: Kozlonyok.hu [10.02.2019.]

1273/2016. Kormányhatározat a honvédelmi kiadások és a hosszú távú tervezés feltételeinek megteremtését szolgáló költségvetési források biztosításáról, [online], 07.06.2016. Source: Net.jogtar.hu [10.02.2019.]

1283/2017. Kormányhatározat a honvédelmi kiadások és a hosszú távú tervezés feltételeinek megteremtését szolgáló költségvetési források biztosításáról szóló 1273/2016. Kormányhatározat módosításáról, [online], 02.06.2017. Source: Net.jogtar.hu [10.02.2019.] 